Cahiers $d u$ MONDE RUSSE

\section{Cahiers du monde russe}

Russie - Empire russe - Union soviétique et États indépendants

$52 / 4 \mid 2011$

Varia

\title{
Tomohiko Uyama, ed., Asiatic Russia
}

David Schimmelpenninck van der Oye

\section{OpenEdition \\ Journals}

\section{Electronic version}

URL: http://journals.openedition.org/monderusse/7588

DOI: 10.4000/monderusse.7588

ISSN: $1777-5388$

\section{Publisher}

Éditions de l'EHESS

\section{Printed version}

Date of publication: 20 December 2011

Number of pages: $695-696$

ISBN: 978-2-7132-2353-2

ISSN: $1252-6576$

\section{Electronic reference}

David Schimmelpenninck van der Oye, «Tomohiko Uyama, ed., Asiatic Russia », Cahiers du monde russe [Online], 52/4 | 2011, Online since 28 November 2012, Connection on 22 September 2020. URL http://journals.openedition.org/monderusse/7588; DOI : https://doi.org/10.4000/monderusse.7588

This text was automatically generated on 22 September 2020

@ École des hautes études en sciences sociales 


\title{
Tomohiko Uyama, ed., Asiatic Russia
}

\author{
David Schimmelpenninck van der Oye
}

\section{REFERENCES}

Tomohiko UYAMA, ed., Asiatic Russia. Imperial Power in Regional and International Contexts. Abingdon - New York : Routledge, 2012, 296 p. (New horizons in Islamic studies - Second series)

1 Since at least the early seventeenth century the bulk of its territory has lain in Asia, but scholars have only seriously begun to pay much attention to Russia's East over the past two decades. Nevertheless, the field has made substantial progress, as a growing number of books, symposia, and dissertations suggest. A case in point is the essay collection, Asiatic Russia: Imperial Power in Regional and International Contexts. The volume is the outcome of a conference in 2007 at Hokkaido University's Slavic Research Center, an institution with a unique expertise in the subject. Its thirteen papers reflect the SRC's cosmopolitan orientation, with contributions from Russian, Japanese, American, European and Central Asian specialists.

Organised around four topics - expansion, institutions and demography, foreign policy (broadly defined), and nationalism - the chapters range from the high politics of empire to its colonial intermediaries and subjects. Among the former, three stand out, including Matsuzato Kimitako on the autocracy's efforts to strike the right balance between efficiently managing vast new territories and discouraging potentially separatist tendencies, as well as Sergei Abashin's discussion of the exceedingly difficult task of merely counting the population of newly-acquired lands. The late Anatolii Remnev's fascinating essay about “internal imperialism" by Russifying far-flung peripheral lands through peasant colonisation reminds us that the Siberian scholar's premature death is a tragic loss for the discipline. As Remnev points out, encouraging Russian migration to the empire's eastern marches at times actually weakened Saint Petersburg's hold by alienating the local population. 
One of the more welcome consequences of the Soviet Union's collapse for Russian history has been the easing of ideological tensions among its practitioners. Rather than excoriate or justify tsarist colonialism, younger scholars now tend to approach the subject with more clinical objectivity. This is particularly important when studying the role of the Russian empire's collaborators and other intermediaries, as do several of the collection's authors. Robert Crews (who also participated in the volume) already suggested that the relationship between the Orthodox Christian Romanovs and the mullahs of his Islamic subjects was not inherently antagonistic in his For Prophet and Tsar. ${ }^{1}$ Thus chapters by Hamamoto Hami, Gulmira Sultangalieva and Noda Jin examine the often symbiotic relationship between imperial ambitions and Tatars under Russian rule. Indeed, writing about domesticating the Kazakh steppe, one tsarist contemporary argued "Tatars and mosques constituted the bridge that the Kirgiz would initially cross in the process of rapprochement with Russians." (p. 55)

of course, such cooperation could only function when the autocracy remained relatively tolerant of other cultures and faiths. Sultangalieva goes on to describe how the relationship between officials and Islamic intermediaries began to sour in the more hostile climate of Russian nationalism in the waning decades of the Romanov dynasty. Much like Newton's third law of physics, Russification began an equal and opposite reaction by inspiring national consciousness among the empire's various Asian ethnicities, as Salavat Ishakov and the volume's editor, Uyama Tomohiko, point out in their essays.

Asiatic Russia focuses on Russia's Islamic realms. However, one chapter by the Buriat Nikolay Tserempilov examines the unusual relationship between Saint Petersburg and the Buddhist East. The Romanov's relatively benign approach to its own Buriat and Kalmyk subjects, many of whom worshipped according to the Gelugpa sect of the Dalai Lama in Tibet encouraged the latter to seek tsarist protection from his more predatory neighbours in China and British India at the turn of the twentieth century. The story of his envoy, Agvan Dorzhiev, has already been well told by Aleksandr Andreev, among others. ${ }^{2}$ However, Tserempilov's discovery of a hitherto unknown cache of the Thirteenth Dalai Lama's correspondence with Dorzhiev shed new light on this intriguing episode.

6 Collecting a volume of essays by such a varied group of scholars inevitably results in a rather diffused perspective on "Asiatic Russia." And the book may be somewhat bewildering for the novice. At the same time, the generally high quality of the contributions, thoroughly grounded in the archives, will be welcomed by the growing number of specialists in the field.

\section{NOTES}

1. Robert Crews, For Prophet and Tsar: Islam and Empire in Russia and Central Asia, Cambridge, MA: Harvard University Press, 2006. 
2. A.I. Andreev, Tibet $v$ politke tsarskoi, sovetskoi i postsovetskoi Rossii, SPb.: St Petersburg University Press - Nartang, 2006. 